This item was submitted to Loughborough's Research Repository by the author.

Items in Figshare are protected by copyright, with all rights reserved, unless otherwise indicated.

\title{
Suffering angels: death and femininity in Ellen Wood's fiction
}

PLEASE CITE THE PUBLISHED VERSION

http://dx.doi.org/10.1080/09699080802173756

\section{PUBLISHER}

Routledge (@ Taylor and Francis)

VERSION

AM (Accepted Manuscript)

LICENCE

CC BY-NC-ND 4.0

REPOSITORY RECORD

Beller, Anne-Marie. 2019. "Suffering Angels: Death and Femininity in Ellen Wood's Fiction". figshare. https://hdl.handle.net/2134/6695. 
This item was submitted to Loughborough's Institutional Repository (https://dspace.lboro.ac.uk/) by the author and is made available under the following Creative Commons Licence conditions.

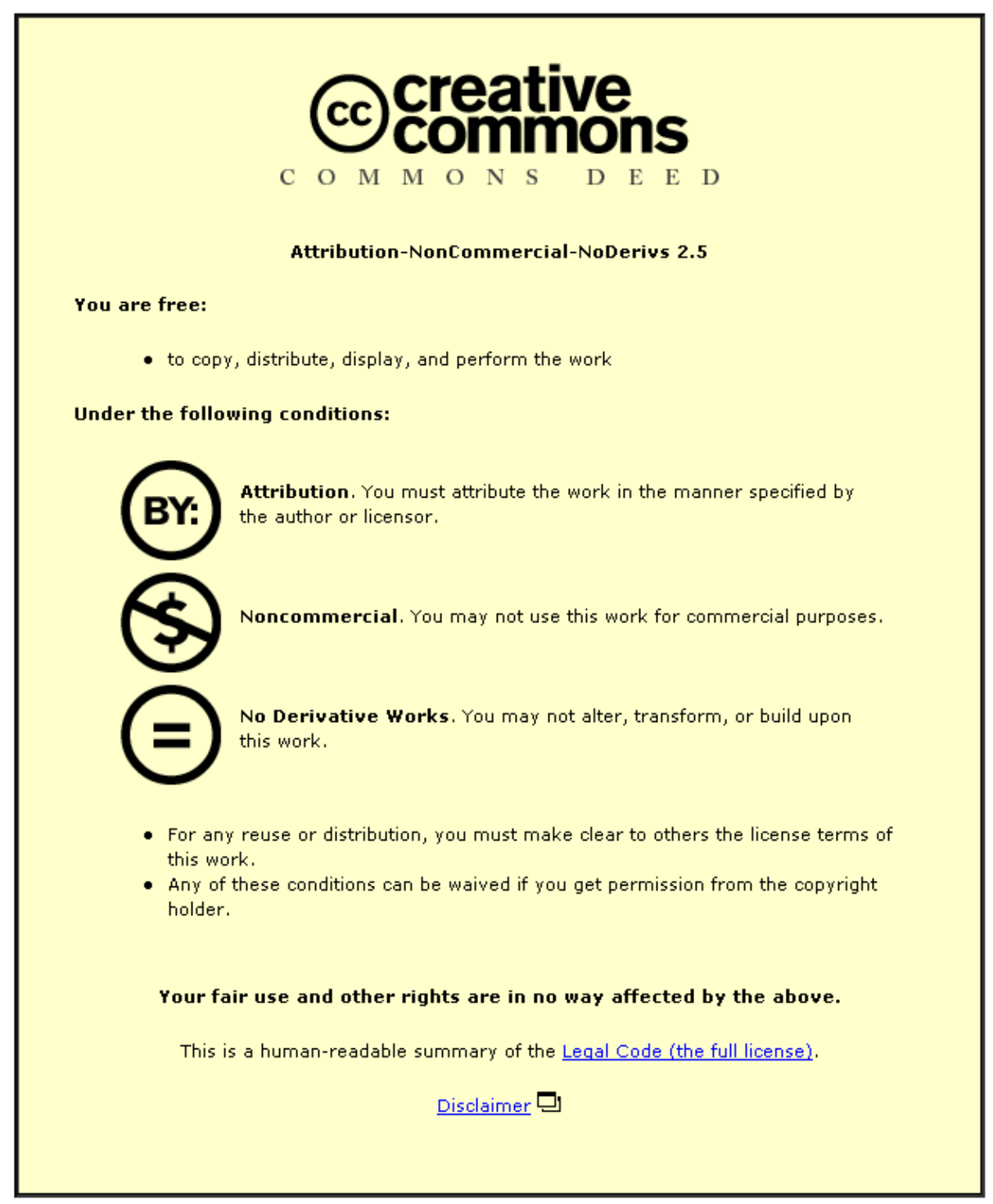

For the full text of this licence, please go to: http://creativecommons.org/licenses/by-nc-nd/2.5/ 


\title{
Suffering Angels: Death and Femininity in Ellen Wood's $\underline{\text { Fiction }}$
}

\begin{abstract}
Anne-Marie Beller
She was dead. No sleep so beautiful and calm, so free from trace of pain, so fair to look upon. She seemed a creature fresh from the hand of God, and waiting for the breath of life; not one who had lived and suffered death. ${ }^{1}$
\end{abstract}

Death-bed scenes in Victorian fiction, whether treated in a melodramatic, sentimental, or overtly didactic manner, drew on a collective cultural understanding and were immensely popular with the reading public. The Victorian preoccupation with death, evident throughout the period's art and literature, can be viewed according to Pat Jalland as "an honest realism given relatively high mortality rates" and it is perhaps unsurprising that fiction came to provide a space in which this shared cultural concern could be explored and negotiated. ${ }^{2}$

Nowhere is the fascination with death more apparent than in the immensely popular novels of Mrs Henry Wood, where the presence of sickness and dying is ubiquitous. Yet, because of the neglect of Wood's wider oeuvre the deaths of Lady Isabel and William Carlyle, in her most famous novel East Lynne (1861), have tended to set the tone for reading her treatment of death and, indeed, to shape attitudes to her fiction more generally. Lady Isabel's death is seen as morbidly sentimental and didactic, an evaluation that inclines to support the dominant critical construction of Wood as a conservative writer, whose novels work to uphold conventional morality and orthodox views. In keeping with this perception, Lady Isabel's death is generally viewed as punitive, a punishment inflicted by Wood as the penalty for her heroine's adultery. Thus, Winifred Hughes argues that Wood "preserves the conventional meanings of stage melodrama, 
while herself doing much to foster the increasing tendency of the heroine to die of $\sin ^{\text {". }}{ }^{3}$ Similarly, Kimberley Reynolds and Nicola Humble claim that Isabel's adultery “is an act motivated by lust and, as such, is finally expiable only by the heroine's death". ${ }^{4}$ Stevie Davies sees East Lynne as endorsing the "barbaric and primitive" Victorian sexual code for women, stating that "[i]ts morality is retributive and unforgiving", and Lyn Pykett seemingly concurs with the death-as-punishment approach when she comments that "the wages of all this sinning turn out, after all (reassuringly), to be death". ${ }^{5}$

In this essay I want to argue that Wood's treatment of death is more complex and interesting than such accounts would suggest, and that an appraisal of this topic beyond East Lynne demonstrates the inadequacy of reading death simply as a form of textual punishment for transgressive heroines. I will discuss the deaths of female characters in The Shadow of Ashlydyat (1864) and Verner's Pride (1863), to demonstrate that Wood is caught between two key representational paradigms - one religious and the other artistic - which results in an ambiguity in her portrayal of death. Although men, women, and children are all the subjects of deathbed scenes in her fiction, I want to focus on female death because it is here that the ambiguity I identify is most apparent. For while the deaths of men and children are frequently modelled more clearly on the religious ideal of the "good death", there is a tension in the depiction of the dying heroine between a Christian eschatology and the representational codes of contemporary visual art and literature, which repeatedly encoded the dead or dying woman within a rhetoric of fallenness. The tension, then, is one between spiritual and worldly concerns, and between death as "heavenly reward" and death as "punishment". I will argue that Wood's negotiation of death in her novels is inextricably connected to her ideas about femininity, 
and that a close analysis of the deaths of female characters in Wood's wider oeuvre facilitates new ways of reading Isabel Vane's more famous demise in East Lynne.

Wood's depictions of death are influenced by two overlapping, but also conflicting traditions. On the one hand she draws on the religious rituals and beliefs surrounding death during the mid-Victorian period. As Pat Jalland's research has demonstrated, the "Evangelical revival had a profound effect on the way the Victorian family approached death" and, inevitably, this carried over into fictional portrayals of dying. ${ }^{6}$ Wood's deathbed scenes generally incorporate many of the key elements of the "good" Christian death, as it was popularly understood in the 1860s:

Death ideally should take place at home [....] The dying person should be conscious and lucid until the end, resigned to God's will, able to beg forgiveness for past sins and to prove his or her worthiness for salvation. Pain and suffering should be borne with fortitude, and even welcomed as a final test of fitness for heaven and a willingness to pay for past sins. $^{7}$

This 'good death' of the Christian tradition, revitalised by the evangelical movement, is encapsulated by male figures in Wood's novels, for example in the Christ-like suffering and stoicism of Henry Arkell and the edifying last words of Edgar Halliburton to his children. ${ }^{8}$ Yet in her depictions of the dying heroine, there is an additional engagement with the artistic iconography of the day, which complicates the Christian model by intruding a specifically gendered aesthetic. Work by feminist cultural historians and literary critics has demonstrated a persistent cult of the idealised female corpse. From Shakespeare's Ophelia to Richardson's Clarissa, the death of the beautiful woman has been fetishised, her ultimate condition of stasis and passivity seen to represent the apotheosis of feminine perfection. In the Victorian period, this tendency is most evident in the numerous paintings of dead or dying women, the popularity of which tend to support Edgar Allan Poe's assertion that "the death of a beautiful woman is, 
unquestionably, the most poetic subject in the world". ${ }^{9}$ Elisabeth Bronfen has also argued that "the interstice between death, femininity and aesthetics is negotiated over the representation of a dead feminine body clearly marked as being other", ${ }^{10}$ and it is this "otherness" that effectively differentiates the deaths of women from those of men or children in Wood's fiction. Female death in these texts is invariably figured as spectacle, and used to display (and sometimes question) fundamental principles of idealised femininity. As Bronfen suggests:

The construction of Woman-as-Other serves rhetorically to dynamise a social order, while her death marks the end of this period of change. Over her dead body, cultural norms are reconfirmed or secured, whether because the sacrifice of the virtuous innocent woman serves a social critique and transformation or because a sacrifice of the dangerous woman reestablishes an order that was momentarily suspended due to her presence. ${ }^{11}$

Both of these scenarios are present in Wood's fiction, though in modified or altered forms. The deaths of virtuous women in The Shadow of Ashlydyat may be read as a critique of gender roles, but they can also be interpreted in more nuanced and complex ways, as we shall see. Similarly, though Verner's Pride does offer an example of the "dangerous woman", whose death enables the reinstatement of a temporarily disrupted order, it does so in a spectacularly ambiguous manner. However, this is not to refute Bronfen's thesis, merely to suggest (as she herself does) that the relationship of the woman writer to this cultural mythology of feminine death is more complex than that of male authors and artists: "Because the historically real woman writer can not articulate herself entirely devoid of cultural fictions of femininity, writing as a woman transpires into an act of reading cultural texts ... critically, so as to enact the implied contradiction". ${ }^{12}$ In order to explore these claims in greater depth, I will turn now to the "suffering angels" of The Shadow of Ashlydyat, before offering a reading of the deaths of the "wayward angels" in Verner's Pride. 
The Shadow of Ashlydyat is a novel obsessed with sickness and death, a fact which even the narrator feels compelled to acknowledge: "You will deem this a sad story; perhaps bring a reproach upon me for recording such. That bell has tolled out all too often in its history; and this is not the first funeral you have seen at All Soul's". ${ }^{13}$ It tells the story of the last generation of the ancient Godolphin family, owners of Ashlydyat and a respected banking house, and focuses particularly on the lives of the Godolphin brothers, Thomas and George. Patient, noble, and responsible, the elder brother Thomas is in love with gentle and ladylike Ethel Grame, who dies early in the narrative through selflessly nursing her unpleasant sister through a bout of typhoid fever. Ethel's death encapsulates both the ideals of the "good Christian death" and the idealized sentimental death of contemporary art and fiction. When Thomas enters the bedchamber he sees the body of his fiancée "laid out in her white night-dress [...] Pale, still, pure, her face was wonderfully like what it had been in life, and a calm smile rested upon it" (98). As with Dickens's Little Nell, there are references to angels and the unchanged beauty of both women, staples of the "good" death, which ensure that the perfection exhibited by the woman in life is preserved in the moment of transition. Ethel's serene corpse offers the comfort of belief in a heavenly existence, where earthly suffering will cease. Yet it also fetishises her body as an object of beauty and desire for the male gaze. Ethel's death foregrounds the idea of the "suffering angel" and anticipates the story of Maria Godolphin, whose narrative of resigned suffering is the one of the central concerns of the novel.

Thomas's reckless and handsome younger brother, George Godolphin, is torn between his love for the local clergyman's demure daughter, Maria Hastings, and an 
attraction to the independent-minded Charlotte Pain, who appeals to his wilder, hedonistic side. Though he marries Wood's "good" woman, Maria, George is nevertheless led into gambling and profligacy by Charlotte's disreputable brother-in-law, Mr. Verrall, and gradually falls heavily into debt. He also continues to be intimately involved with Charlotte after his marriage, though Maria in her innocence remains blind to the true nature of their relationship: "could she have divined that Mr. George's tender adieux sometimes strayed elsewhere! - that his confidences were given, but not to her!" (217). George tries to extricate himself from his difficulties by embezzling funds from the family bank and, in a familiar mid-Victorian plot, there is a run on the bank leading to its collapse and the ruin of the Godolphin family.

As the narrator repeatedly implies, George's actions are the direct cause of his wife's gradual decline and death. Maria is gentle and meek, embodying Wood's notion of the true "lady", and the most consistent outward signs of her status as a "lady" are weakness, passivity, and delicate health. As Lynda Nead has noted, "[f]emale dependency was reproduced and guaranteed by the belief that respectable women were inherently weak and delicate, and were in a perpetual state of sickness". ${ }^{14}$ Indeed, it is Maria's perfect conformity to Wood's concept of the lady that proves to be responsible for her death, which is celebrated in the sense that it provides the ultimate proof of her quintessential femininity.

Early in the novel the reader is informed that "Maria ... was rather addicted to doing nothing" (51), a phrase which might have served for her epitaph, so apposite a description is it of Maria's inaction and resignation throughout the narrative. When George's selfish actions bring bankruptcy and shame on them and he ignobly runs off to London leaving 
his wife to cope alone with angry creditors and the outrage of the town, Maria embraces a martyrdom that Wood conveys as heroic. Always delicate, Maria lacks the strength, both mental and physical, to endure what she repeatedly refers to as "the troubles". After the disclosure of George's disgrace, and throughout the remainder of the novel, Maria alternates between bouts of tears and a debilitating self-pity, while constantly informing the other characters of her impending death: “'Mamma's not well,' said Meta .... 'Mamma cries often. She was crying this morning... mamma says she's going to heaven"” (422).

Maria's ladylike fragility is emphasised in the novel through contrast with her foil, Charlotte Pain, whose "full, red lips" and "large eyes, made to dazzle rather than to attract ... told of power; but not of innate refinement" (50-1). Charlotte's power, selfreliance, and courage are the converse of Maria's delicacy and, significantly, even Charlotte's physical health is conveyed in negative terms, presented as a badge of her vulgarity, in contrast to the refined weakness of Maria. Jeanne B. Elliott has described the typical virtues associated with the ideal of the Victorian Lady, in terms that emphasise the contrast between Wood's two characters:

She was nearly always required to be self-disciplined and self-contained .... In dress and demeanour she was modest; she was restrained from any ostentatious or flamboyant behaviour .... Inevitably she was patient and long-suffering, passive under injustice and unfair treatment .... the ideal of the Lady included a degree of physical frailty. ${ }^{15}$

This account accurately reflects Maria's characterisation, while Charlotte represents its antithesis. Flamboyant and unconventional in dress and manners alike, with no interest in the traditional aspirations of women, Charlotte anticipates Eliza Lynn Linton's "girl of the period" and can neither comprehend nor sympathise with Maria's aptitude for suffering. ${ }^{16}$ 
Maria, on the other hand, embraces death: "If it were not for Meta [her daughter], I should be glad to die" (423) - and her morbid sensitivity, coupled with an acute apathy, lead to her actual death, which Wood manages to draw out for over twenty chapters. ${ }^{17}$ The negativity of Maria's resignation is never really questioned, but is indeed admired as proof of the woman's innate sensibility. Sally Mitchell has proposed that “when women's sexual needs and desires are suppressed and when society encourages - or even demands - the formation of a dependent character, the consequence is likely to be a masochistic personality". ${ }^{18}$ Maria's undoubted masochism is a key part of her status as a Lady, and once again her behaviour is explicitly compared with Charlotte's strength, to the obvious detriment of the latter:

...the troubles of one kind and another had been too much for [Maria]; she was dying of them; ... that delicate, refined, sensitive woman .... You may remember it was observed at the beginning of her history that she was one unfit to battle with the world's sharp storms - it had now proved so. Charlotte Pain would have braved them, ... have weathered them jauntily on a prancing saddle-horse; Maria had shrunk down, crushed by their weight. Il y a - let me once more repeat it - Il y a des femmes et des femmes. (481)

The reader is left in no doubt as to which sort of woman Wood approves. The final vindication of Maria's behaviour is proffered by her husband, who assures his dying wife that "men do not marry women such as Charlotte Pain" (480).

Significantly, Maria's death reforms her husband, and the novel's closure witnesses George Godolphin, chastened and wiser, embarking on a new and more respectable career in India. And whereas Elliott argues that Isabel Vane's "tragic fate ... arises from her inability to live up to the ideal of the Lady", I would suggest that Maria's death ensues as a direct result of her too precise embodiment of the "Lady". ${ }^{19}$ It also operates as a form of masochistic fantasy, in which the powerless Victorian wife is able to exert some influence over the rakish and irresponsible husband, a reading that is supported by 
the prolonged deathbed scene of repentance and forgiveness. In this sense, the death serves as a vehicle for the punishment of George, rather than Maria, as the errant husband is forced to a devastating awareness of his transgressions: "The troubles have not killed you, have they, Maria?" (477). His dying wife's answer in the affirmative is equivalent to an admission that he is responsible, as is her deathbed plea for him not to marry Charlotte Pain who, Maria claims, "has helped to kill me" (479). ${ }^{20}$

Maria Godolphin's death has compelling similarities in treatment to that of Isabel Vane in East Lynne. As noted previously, critics have tended to view Isabel's death as a necessary textual punishment for her transgressions, albeit one whereby she manages to retain the sympathies of the reader. Winifred Hughes, for example, suggests that "for the adulteress $[\ldots]$ there is only one permissible cure, morally as well as dramatically: an early and contrite death". ${ }^{21}$ Yet this is to misconstrue Wood's moral ideology, as well as to ignore the fact that adulteresses do evade the death penalty in Wood's fiction. ${ }^{22}$ If one places Isabel's famous demise within the wider context of Wood's work, it becomes clear that, for Wood, death cannot be considered a punishment in any straightforward way. Generally, Wood bestows a youthful death in recognition, even in reward, of goodness. Thus, in The Shadow of Ashlydyat, Thomas Godolphin and his young fiancée Ethel, figures of patient endurance and self-sacrifice like Maria, also die prematurely. That the characters who transgress in some way are all alive at the close of Wood's narrative would not suggest that the author equates death with punishment. It would therefore be more consistent to read Isabel Vane's death as a final blessing, bestowed by Wood as a recognition of her true goodness and patient suffering. For Isabel, punishment comes not at the end of the novel, but during her life, through the social ostracism and loss of her 
children and husband. That Isabel finally dies can be seen as an acknowledgement of Wood's belief in her worth, despite her fall. For "bad" women do not inevitably die in Wood's novels, whereas "good" women become literal manifestations of Coventry Patmore's "angel", triumphing in death as true representations of a Victorian ideal.

In Verner's Pride ${ }^{23}$, Wood again explores links in the cultural representation of femininity and death, but here the treatment of the dying woman is quite different. The fate of Sibylla West offers a subversion of the "good death", as exemplified by Maria Godolphin and Ethel Grame, and demonstrates clearly how notions of the "beautiful death" are embedded firmly within contemporary constructions of femininity. The novel opens with the drowning of Rachel Frost, a servant of Verner's Pride, who is later revealed by the autopsy to have been pregnant. Rachel's suicide is, of course, a "bad death" in religious terms, but the presentation is influenced significantly by the codes of contemporary art and certain literary traditions that would have resonated with Wood's readers. For Victorians, suicide by drowning held such strong associations with the powerful cultural myth of the fallen woman that the nature of Rachel's death would have immediately elicited conjectures regarding her sexual purity. As Lynda Nead has suggested of the tradition of the fallen woman, "[i]t is difficult to over-emphasise the potency of the mythology within cultural discourse: it permeated all forms of cultural representation from high art to the more popular forms of culture". ${ }^{24}$ In a wider context, drowning is also frequently seen as "the traditional feminine literary death" through perceived links between "femininity and liquidity". ${ }^{25}$

Wood's depiction of Rachel Frost's death draws implicitly on the cultural iconography of the death of the beautiful woman. Rachel drowns herself in a pool known 
locally as the "willow pond", due to the profusion of weeping willows that surround it, which immediately evokes Gertrude's description of the watery death of Ophelia in Hamlet and, more specifically for a Victorian reader, John Everett Millais's painting of this scene. Wood uses the allusion to Ophelia to position Rachel's suicide within a whole system of references - unrequited love, fallen women, seduction, abandonment - which work to construct Rachel as sympathetic victim, rather than dangerous transgressor. By opening the novel with Rachel's suicide, Wood foregrounds the themes of female selfdestruction and disruptive sexuality, which subsequently inform interpretations of the death of Sibylla West. There are also implicit links between the two women, which similarly encourage a reading of their deaths as symbolically related. ${ }^{26}$

Sibylla West embodies the defiant spirit of Charlotte Pain within the frail constitution of Maria Godolphin. Early on in the novel, Sibylla is caught in the act of admiring her own reflection in the mirror by her suitor, Lionel Verner, and she pretends that a moth caught in a tumbler is the real object of her attention. The narrator chooses to describe Sibylla as a "vain butterfly ... who was gay and fluttering, and really of little more use in life than the moth" (72). The butterfly / moth simile points to the two sides of Sibylla: on the one hand she is a gay and colourful social butterfly, whose "two ruling passions [...] were vanity and ambition" (72); yet, she is also the moth, a symbol of death in many cultures, whose fragility and ephemerality are foreshadowed from the beginning. ${ }^{27}$

After her first husband, Fred Massingbird, dies, Sibylla manages to manipulate Lionel into proposing. Too late, Lionel realises that he has mistaken his infatuation for love, and that his true affections lie elsewhere. However, Lionel is the epitome of a gentleman and buries his feelings, indulging Sibylla's every whim, even though her passion for fine 
clothes and lavish entertainments brings him to the brink of financial ruin. Significantly, the only times that Lionel does allow himself to criticise his wife are when she deviates from the ideal of ladylike behaviour: "that his wife had shown herself so entirely unlike a lady did disturb him" (252).

Rachel too is problematically positioned in relation to the cult of the Lady. Though a servant, "she looked gentle and refined as any lady, and her manners and speech would not have destroyed the illusion" (6). Rachel seems like a lady, but is not; Sibylla is a lady by social position, but not by temperament. This failure to measure up to the ideal of the lady is reflected in their inability to meet death nobly like Ethel and Maria. In Sibylla, calm resignation is replaced by defiance and her repeated petulant complaint of "I don't want to die" (453-4). The consumptive disorder to which Sibylla is constitutionally inclined is paradoxically at odds with her exuberant personality and hedonistic enjoyment of life, and even as her body succumbs to the illness, her spirit remains indomitable.

Ordered not to attend a ball through fear that the excitement could kill her, Sibylla disregards the advice of both her doctors and her husband, refusing to be denied an opportunity for pleasure. Wood's description of Sibylla dressing for the ball gives the impression that she is virtually a corpse already, while the fact that she is trying on wreaths, which can also denote funereal tributes, takes on a significant ambiguity: "The dead white of the roses was not more utterly colourless than Sibylla's face. She was like a ghost: she often looked so now" (427). The fact that Sibylla is in full ball attire somehow makes her deteriorated state seem more indecent. Wood describes her as "très décolletèe", which draws attention to her wasted charms; the sexuality she used so effectively in the past has become something grotesque. Her brother-in-law Jan 
comments that "[h]er shoulders looked like a bag of bones. You might almost have heard them rattle" (452). Sibylla has become a parody of a desirable woman.

In stark contrast to the romanticised images of dying women in contemporary artworks, Wood presents Sibylla as something monstrous, a living corpse:

Standing there was Mrs Verner: looking like - more like a bedecked skeleton than anything else. She was in fairy attire. A white gossamer robe, with shining ornaments, and a wreath that seemed to sparkle with dewdrops on her head. But her arms were wasted; the bones of her poor neck seemed to rattle as they heaved painfully under the gems clasped round it; and her face had not so much as the faintest tinge of hectic, but was utterly colourless; wan; ghastly. A distressing sight to look upon... (436)

Sibylla is a distressing sight because she contravenes the required passivity of both the "good" and the "beautiful" female death. Instead of the submissive acceptance that characterises both the Christian model and dominant artistic representations such as Millais's Ophelia, Sibylla's final actions are distinguished by a refusal to depart from life in anything other than a whirl of defiant gaiety. By insisting on attending the ball Sibylla refuses to conform to her assigned role - that of dying beautifully and angelically at home, in the manner of Maria Godolphin. Her hedonism and her stubbornness lead her literally to dance herself to death and, interestingly, Jan evokes the circumstances of Rachel's suicide when he warns her not to dance: "You must not do it, Sibylla. There's a pond outside: you might just as well go and throw yourself into that" (450). The implied connection to Rachel's suicide emphasises the active part Sibylla has played in her own death. ${ }^{28}$

Demure reticence and innate modesty are fundamental to Wood's notion of the Lady. Thus, Sibylla's spectacular display of herself at the ball violates the central tenets of appropriate feminine behaviour. The scenes of Sibylla dancing herself to death are analogous to a remarkable episode in Wood's 1866 novel, St. Martin's Eve ${ }^{29}$, in which 
the corpse of Adeline de Castella holds a reception. In keeping with an old French custom, Adeline's dead body is elaborately dressed in bridal clothes and placed and fixed into position, ready to "welcome" the company who are to come and view her for the last time. Adeline's death is presented as an aesthetic event and, in one sense, the logical culmination of her life since, as Andrew Mangham points out, in life too, she "is framed and objectified as an art object throughout". ${ }^{30}$ The scene would seem to exemplify the cultural tradition of female corpse as spectacle that Bronfen discusses, whereby "an image of a beautiful dead woman [is] exhibited for the gratification of her viewers" ${ }^{31}$ Yet in Wood's hands, this gratification becomes something more ambiguous. The display of Adeline's body, described variously as "a show" (361) and "the exhibition" (356), produces feelings of repulsion and horror (in the narrator as well as specific characters). The finery of her costume "could not conceal the ghastliness of the features, or soften the fixed stare of the glazed eyes" (363). Pinned and displayed like a butterfly, a dead virgin in bridal clothes, Adeline is the ultimate fetishised object. However, unlike Ethel Grame and Maria Godolphin, who are beatific in death, the exhibited corpse of Adeline and the living corpse of Sibylla evoke fear:

What was it that had broken in on them? What object was that, gliding into the room like a ghost, on whom all eyes were strained with a terrible fascination? Was it a ghost? It appeared ghastly enough for one [...] A skeleton bedizened with jewels. (Verner's Pride, 448)

Sibylla is an object, a ghastly thing, a ghost, a skeleton. Stripped of her femininity, even her humanity, she becomes a thing of horror: "'What is it?' ejaculated Sir Edmund, gazing with something very like fear, as the spectre bore down towards him" (448, emphasis added). I would suggest that Sibylla is able to provoke such extreme reactions because she has violated, not only the principles of the "lady", but also the domestication 
of death associated with that construction. Whereas Maria Godolphin embodies the ideals of the Victorian Lady in her patient suffering as she waits at home to die, Sibylla spectacularly rejects those ideals, even up to "her last dance on earth" (451).

In conclusion, the "suffering angels" in The Shadow of Ashlydyat and the "wayward angels" of Verner's Pride demonstrate the multiple ways in which Wood depicts the relationship between death and femininity in her fiction. In each of these cases, the manner in which a female character dies dramatises the specific constructions of femininity she has negotiated during life. What also becomes apparent is the arguably self-destructive nature of femininity in these novels. Rachel Frost's suicide is only the explicit example of a vein of self-destruction inherent in Wood's heroines. In different ways both Sibylla and Maria destroy themselves: Sibylla through a defiant challenge to the feminine ideal, Maria through embodying that ideal yet also using her passivity in an extreme bid to exercise power where she had been powerless. Wood is both influenced by and resistant to the powerful contemporary cultural representations of dying and femininity, and in her novels death is rarely a straightforward punishment for female transgression, but rather the site at which conflicting constructions of femininity collide and are negotiated.

\section{Notes}

\footnotetext{
${ }^{1}$ Little Nell's death in Charles Dickens, The Old Curiosity Shop, ed. Norman Page (1841; London: Penguin, 2000) 538.

${ }^{2}$ Pat Jalland, Death in the Victorian Family (Oxford: Oxford UP, 1996) 5.

${ }^{3}$ Winifred Hughes, The Maniac in the Cellar: Sensation Novels of the 1860s (Michigan: Ann Arbour, UMI, 1997) 109.

${ }^{4}$ Kimberley Reynolds and Nicola Humble, Victorian Heroines: Representations of Femininity in Nineteenth Century Literature and Art (Hertfordshire: Harvester Wheatsheaf, 1993) 113.

5 Stevie Davies, “Mrs Henry Wood's East Lynne: Introduction,” U of Manchester, 1984 <http://www.steviedavies.com/henrywood.html> 1984 ; Lyn Pykett, The Sensation Novel: From The Woman in White to The Moonstone (Plymouth: Northcote, 1994) 60.

${ }^{6}$ Jalland 2.
} 


\footnotetext{
${ }^{7}$ Jalland 26.

${ }^{8}$ These characters appear respectively in Mildred Arkell (1865) and Mrs Halliburton's Troubles (1862).

${ }^{9}$ Edgar Allan Poe, "The Philosophy of Composition," Essays and Reviews (New York: Literary Classics of the United States, 1984) 19. Some well-known paintings of dead or dying women in the Victorian period include John Everett Millais's "Ophelia" and "The Lady of Shallot", the numerous "fallen women" paintings such as E. Barnes's “The Bridge of Sighs”, G. F. Watt's "Found Drowned”, E. Fitzpatrick's "The Unfortunate" and many others. See Lynda Nead, Myths of Sexuality: Representations of Women in Victorian Britain (Oxford: Blackwell, 1988) and Elisabeth Bronfen, Over Her Dead Body: Death, Femininity, and the Aesthetic (Manchester: Manchester University Press, 1992).

${ }^{10}$ Bronfen xi.

${ }^{11}$ Bronfen 181

12 Bronfen 404

${ }^{13}$ Mrs Henry Wood, The Shadow of Ashlydyat ([1863;] London: Ward, Lock \& Co., 1910) 440. All subsequent references are to this edition and appear in the body of the text.

${ }^{14}$ Lynda Nead 29.

15 Jeanne B. Elliott, “A Lady to the End: The Case of Isabel Vane,” Victorian Studies 19 (March 1976) 329 -344 (332-3).

${ }^{16}$ See Eliza Lynn Linton, "The Girl of the Period”, Saturday Review (14 Mar. 1868): 339-40.

${ }^{17}$ Maria's lingering death actually lasts for about sixty pages, but it is foreshadowed by Wood, and seen as inevitable by Maria herself, for the entire last quarter of the novel.

${ }^{18}$ Sally Mitchell, "Sentiment and Suffering: Women's Recreational Reading in the 1860s," Victorian Studies 21 (1977) 29-45 (40).

${ }^{19}$ Elliott 331

${ }^{20}$ My reading here differs from that of Emma Liggins, who sees Maria's death as a punishment for her failures in household management. While agreeing broadly with Liggins's account of Maria's domestic shortcomings, I feel that her death should not be read as a punishment since the narrator clearly holds up Maria's refinement and ladylike character as an exemplar. See Liggins, "Good Housekeeping? Domestic Economy and Suffering Wives in Mrs Henry Wood's Early Fiction”, Feminist Readings of Victorian Popular Texts: Divergent Femininities, ed. Emma Liggins and Daniel Duffy (Aldershot: Ashgate, 2001) 53-68 (62-64).

${ }^{21}$ Hughes 112-13.

${ }^{22}$ For example, Affy Hallijohn in East Lynne. Critics have generally accounted for the difference in treatment between Isabel and Affy in terms of class; the latter's working-class status removes her from the same moral code as the upper-class Isabel. However, Charlotte Pain in The Shadow of Ashlydyat is arguably an example of a middle-class adulteress who is left "unpunished" at the novel's closure.

${ }^{23}$ Mrs Henry Wood, Verner's Pride (1863; London: Macmillan, 1906). All subsequent references are to this edition and appear in the body of the text.

${ }^{24}$ Nead 169.

${ }^{25}$ Elaine Showalter, "Tradition and the Female Talent: The Awakening as a Solitary Book", New Essays on The Awakening, ed. Wendy Martin (Cambridge: Cambridge University Press, 1988) 33-57 (52). Showalter summarises this link in the following way: "As the female body is prone to wetness, blood, milk, tears, and amniotic fluid, so in drowning the woman is immersed in the feminine organic element" (52).

${ }^{26}$ For example, both Rachel and Sibylla are romantically involved with Fred Massingbird; both violate socially prescribed ideals of behaviour for women; both destroy themselves - Rachel through drowning herself, Sibylla through ignoring medical advice.

${ }^{27}$ Andrew Mangham also discusses Sibylla in terms of the moth / butterfly metaphor. See Violent Women and Sensation Fiction: Crime, Medicine, and Victorian Popular Culture (Basingstoke: Palgrave Macmillan, 2007) 160-2.

${ }^{28} \mathrm{Jan}$, who is careless of the niceties of dress and etiquette and lacks an extensive wardrobe, informs his scandalised mother that he is wearing his "funeral suit" to the ball (446), appropriately enough as it becomes in a sense Sibylla's funeral.

${ }^{29}$ Mrs Henry Wood, St. Martin's Eve (1866; London: Richard Bentley, 1896). All subsequent references are to this edition and appear in the body of the text.
} 
${ }^{30}$ Andrew Mangham, “'I See It; But I Cannot Explain It': Female Gothicism and the Narrative of Female Incarceration in the Novels of Mrs Henry Wood", Victorian Gothic: Leeds Working Papers for Victorian Studies 6, ed. Karen Sayer and Rosemary Mitchell (Spring 2003) 81-98 (93).

${ }^{31}$ Bronfen, 100 